\title{
Study on Sound Changes in the Qaratal Dialect of in Modern Uyghur*
}

\author{
Baihetiyaer Imamuniyazi \\ School of Uygur Language and Culture \\ Northwest Minzu University \\ Lanzhou, China 730030
}

\author{
Aimaiti Aihemaiti \\ School of Uygur Language and Culture \\ Northwest Minzu University \\ Lanzhou, China 730030
}

\author{
Mayisiguli Wusuyin** \\ School of Uygur Language and Culture \\ Northwest Minzu University \\ Lanzhou, China 730030 \\ ***Corresponding Author
}

\begin{abstract}
Aksu Qaratal dialect occupies a unique position in the central dialect of Uyghur language. It differs from Uyghur written language in pronunciation and vocabulary. This paper mainly introduces the phonetic and lexical characteristics of Aksu Qaratal dialect, and compares it with Uyghur written language.
\end{abstract}

\section{Keywords - Qaratal dialect; phonetic change; abscission}

\section{INTRODUCTION}

In the long course of historical development, modern Uyghur language has form a distinct dialect differences; modern Uyghur dialects are divided into central dialect, Hotæn dialect and Lopnur dialect, with the main differences among the three dialects being in phonetics. The standard language of central dialect, Hotæn dialect and Lopnur dialect is based on the central dialect, which is typical adherent languages, with the pronunciation of Kulja, Turpan and Urumqi as the standard pronunciation. The supplementary elements of word-formation and configuration are very abundant. ${ }^{1}$

Local dialect is an important constituent part of dialect that includes local dialect. I think that if we imagine that the three dialects of Uyghur are three mothers, and then we set all kinds of local dialect as several children of three mothers. Because the Uyghur language we use is currently the three major dialects that are most widely spoken, the original sounds widely distributed in the three dialects, each of which has its own local dialect. I think that this likes the same principle that several children of three mothers have multiple characteristics. For example, "qaray" is called "qarsinizza" in

*This paper is a phased achievement of the central university special fund project of Northwest Minzu University of the first-level discipline of "Chinese language and literature" - Uygur Literature Research of Chaghatay (319201808112) and Arrangement and Analysis of Babur Works (Risale-I Aruz manual) (31920180018).

Modern Uygur Language written by Tulap Kasmu Youliqi et al.
Turpan dialect, "qararæ" in Kulja area, and "qajlay" in Kashgar area, and "qalan" in Aksu and Qaratal town in Aksu city.

The town of Qaratal/Qartal (originally translated as "Halata") is located in the south-central part of Aksu city, which borders the township of Toqaj in the East and township of Gule Avati, Onus County, Toqaj Township in the south, faces Avati County in the west that is bounded by Aksu New River, and Baishi Tugman Township in the north The total area of the town is 11,028 square kilometers. It has a total population of 451,000 and 7623 households that is composed of Uyghur, Han and Hui nationalities. It has 28 administrative villages, 101 villagers' groups, 3 directly affiliated farms and 22 Stations (places), with the total area of cultivated land being $320,000 \mathrm{mu}^{2}$

The phonetic change in Qaratal dialect. Qaratal dialect also belongs to central dialect, which in fact is different from the central dialect. This paper is closely related to the phonetic change that refers to the phonetic change of vowels and consonants in some syllables due to the influence of adjacent phonemes of adjacent syllables. We call it phonetic change.

Sound change is the phonetic change. When people speak, they do not produce syllables independently, and then syllables form a "flowing speech". The main forms of flowing speech refer to weakening, abscission, alienation, assimilation, transposition and inflexion and epenthesis.

\section{WEAKENING}

Weakening refers to the change of tone quality caused by the weakening of voice volume when speech. The weakening phenomenon that is most commonly and widely used in the Qaratal dialect is as follows:

\footnotetext{
$2 \quad$ Aksu Municipal People's Government Network.
} 
A. Vowel Weakening

1. The situation of "e" weakens to "a"

Literary language

Qaratal dialect

eghizi

His (her) mouth

aghzi

2. The situation of "e" weakens to "i"

$\begin{array}{lll}\text { mehman } & \text { Guest } & \text { miman } \\ \text { kem } & \text { Who } & \text { kim }\end{array}$

3. The situation of "a" changes to "æ"

Literary language

Qaratal dialect

qart

Playing cards

qært

adæm

People

ædæm

4. The situation of "a" changes to "o"

Literary language

Qaratal dialect

$\begin{array}{lll}\text { atam } & \text { My father } & \text { otam } \\ \text { apam } & \text { My mother } & \text { opam }\end{array}$

The case where "a" is changed to "o" when the first person pronoun is added after the noun of "ata/apa" above, but this phenomenon is not present when the second and third person pronouns are added.

5. The situation of "æ" changes to "a"

$\begin{array}{lcc}\text { Literary language } & \text { Qaratal dialect } \\ \text { kæm } & \text { Lack } & \text { kam } \\ \text { jænæ } & \text { Besides } & \text { hina }\end{array}$

6. The situation of " $u$ " changes to "a"

Literary language

Qaratal dialect

$\begin{array}{lll}\text { mundaq } & \text { In this way } & \text { mandax } \\ \text { qumluq } & \text { Desert } & \text { qumlaq }\end{array}$

7. The situation of " $u$ " changes to "i"

juqurlap Up juqirlap

qarighu Hazy people qarghi

8 . The situation of " $\varnothing$ " changes to "y"

Literary language

toj-tøkyn Wedding

Qaratal dialect

øtyk Kneeboot

toj-tykyn

kømyr Charcoal

ytyk

ølyk Death for breathing one's last ylyk

øchürmæk Delete, expunge/ eliminate üchæmæk

9. The situation of "y" changes to "æ"

Such case happens in the post syllable section. Such as:
Literary language

Kømür

Charcoal

Qaratal dialect

øchmæk Delete, expunge/ eliminate üchæmæk

symyrmæk Absorb syæmæk

10. The situation of " $y$ " changes to "i"

Such case happens on the second syllable. Such as :

Literary language

Qaratal dialect

$\begin{array}{lll}\text { tætyr } & \text { Contrary } & \text { tætir } \\ \emptyset \text { nyr } & \text { Cave } & \emptyset \text { ykir }\end{array}$

jytyrvætmæk Be lost jitirvætmæk

11. The situation of "o" changes to "u"

Such case sometimes happens on the front syllable, sometimes in the post syllable part. Such as:

Literary language

Qaratal dialect

$\begin{array}{lll}\text { oti } & \text { grass of ... } & \text { uti } \\ \text { qorsiqim } & \text { My stomach } & \text { qusubum } \\ \text { qolun } & \text { Your hands } & \text { qulun }\end{array}$

B. Weakening of Consonants

1. The situation of " $\mathrm{j}$ " changes to " $\mathrm{h} "$

Literary language

Qaratal dialect

yoshurun Confidential hushrun

2. The situation of "b" changes to "v" or "p", such case can only appear in the sentence, there is no such phenomenon when it is alone.

Literary language

nægæ bardiniz Where go

kirip baq You come in here

Qaratal dialect

qilip beræj

Do it for you

næ vadiniz

kirip paq

3. The situation of " $\eta$ " changes to " $n$ "

Literary language

Qaratal dialect

zængi

Negro/ black skin

zængi

zæ⿹勹巳

Dark blue

zængær

\section{ABSCISSION}

A. Voice Abscission

The main reason is that some tones of unstressed syllables lose their pronunciation due to the rapid flow of speech or the weakening of the intonation of the last syllable. Such as: 


\begin{tabular}{lcc}
\multicolumn{2}{l}{ Literary language } & Qaratal dialect \\
mæhsulat & Output & mæsulat \\
mæhællæ & Population center & mællæ \\
hærqatfan & Moment & hæqatfan \\
ornida & Substitution & onida \\
Qaratal & Qaratal & qartal
\end{tabular}

1. Abscission of vowels

Abscission refers to the fact that some of the sounds in the flowing speech pronounce or disappear due to the contraction and other reasons in the process of continuous pronunciation. This phenomenon is called abscission, also known as sound attenuating. Such as:

\begin{tabular}{lcc}
\multicolumn{2}{l}{$\begin{array}{l}\text { Literary language } \\
\text { qarighu }\end{array}$} & Qaratal dialect \\
chirayini & Put your face & qarghi \\
xapa saldi & Make angry & xap saldi \\
nemæ & What & nim/nem \\
kechæ kyndyz & The whole day & kich kyndyz \\
In the above examples, the lost vowels are "i, a, and $æ "$,
\end{tabular}

\section{Abscission of consonants}

Literary language

$\begin{array}{lcc}\text { orni } & \text { His position } & \text { oni } \\ \text { alsan } & \text { Bought } & \text { акаn } \\ \text { qærzdar } & \text { Balance due to } & \text { qæzda } \\ \text { alsa } & \text { If buy } & \text { asa } \\ \text { mehman } & \text { Guest } & \text { miman } \\ \text { qajrimaq } & \text { Look } & \text { qa:rimaq }\end{array}$

\section{B. Abscission of Syllables}

Such phenomenon exists in Uyghur literary language, and it is not uncommon in local dialect. Some phenomena in the dialects of Southern Xinjiang are cited to elucidate this problem. Such as:

1. Abscission of syllables in vowels

\begin{tabular}{llc}
\multicolumn{2}{l}{ Literary language } & Qaratal dialect \\
barattin & Want to go & bartin \\
nimandaq & What & nimdaq \\
urus & Russian & rus
\end{tabular}

In the above examples, the most frequently dropped syllable is "at, an", etc.

\section{Abscission of syllables in consonants}

Abscission: The lost phenomenon of most commonly used consonants in Qaratal dialect is as follows:

\begin{tabular}{lcc}
\multicolumn{2}{l}{ Literary language } & Qaratal dialect \\
selip & In bags & sep \\
mavu & This & ma \\
inissititut & College & inistut \\
døylyk & Hilly area & døn \\
qumluq & Sand & qum
\end{tabular}

The most commonly used lost syllables here are "si, li, yk, luq", etc.

\section{Phonetic Abscission in Combined Words}

Because of the transfer of stress or the natural harmony of a word consisting of two words, some pronunciation in the middle is often lost. Such as:

\begin{tabular}{llr}
\multicolumn{2}{l}{ Literary language } & Qaratal dialect \\
toxti aka & Tuohe Tige & toxtaka \\
qara ræy & Black & qar ræy \\
char saqal & White mustache & cha saqal \\
sarixan acha & Shaerhan aunt & sarixacha
\end{tabular}

\section{Phonetic Abscission in Flowing Speech}

Sometimes the speaker speaks very fast, and some pronunciations are omitted or left out, which not only does not affect communication, but also makes the language succinct and clear. Such as:

$\begin{array}{ccc}\text { Literary language } & & \text { Qaratal dialect } \\ \text { qilvalsam } & \text { If can do it } & \text { qivasam } \\ \text { kylvalsam } & \text { If I could laugh } & \text { kylvasam } \\ \text { Selvalsam } & \text { Let you do } & \text { sevasam }\end{array}$

\section{E. Syllable Reduction in Flowing Speech}
qiilip beræy
Do for you
qipperæy
tepip beræy
Help you look for
teppiræy

The most commonly used lost syllable here is "ip".

\section{F. Natural Abscission of Phonetics in Context}

Such phenomenon often occurs in sentences or phylum when the speaker speaks very fast sometimes, but there is no lost phenomenon when the word is pronounced alone or separately. Such as:

$$
\text { Literary language Qaratal dialect }
$$

\section{Qaratal dialect}

bu bashqilarnin sovghiti

$$
\text { bu bashqilanin soghiti }
$$

It is a gift of someone else

dadam maya velispit elip bærdi dadam maya vespit eppædi

Father bought a bike for me 


\author{
u axsham mæn bilæn kælgæn \\ u ax Sam mæn bilæn \\ kægæn
}

He came with me last night.

The most commonly used lost syllable is "li" and the lost consonant is " $r, v "$.

\title{
G. The Phenomenon of Consonant Abscission in Words with Complex Phonetic Changes
}

1. Vowels and consonants are lost at the same time:

\section{Literary language}

Qaratal dialect

nægæ bardiniz

Where have you been

næ vadiniz

mæslihæt

Discussion

mæslæt

The above is the phenomenon of vowel abscission firstly and then the consonant abscission.

Literary language

Qaratal dialect

qorsiqim

My stomach

qusqum

dærja

River

dej

ajropilan

Plane

arpilan

The above is the phenomenon of the consonant abscission firstly and then the vowel abscission. There will also be the following situation in the Qaratal dialect.
Literary language
Qaratal dialect
yoshurun
Confidential
hushrun

The main phenomenon happened of the above examples is: the consonant " $\mathrm{j}$ " changes to " $\mathrm{h}$ ", the vowel "o" changes to "u", and the vowel "u" is lost.

$\begin{array}{lcl}\text { Literary language } & & \text { Qaratal dialect } \\ \text { qurbanliq } & \text { Livestock } & \text { qurvanliq } \\ \text { japalarni tartqan } & \text { Hard } & \text { japalini tatqan } \\ \text { zænjir } & \text { Necklace } & \text { zenngi } \\ \text { bir } & \text { One } & \text { bi }\end{array}$

What happens here is that "b" changes to "v", vowel "a" weakens to "i", and two " $r$ " is lost, and that vowel "æ" weakens to "e" and the consonant " $r$ " is lost. The " $r$ " in the word "zændzir" can only be found in Kashgar area and Qaratal dialect. But the word " $r$ " in "bir" can only be found in Qaratal dialect. Such as: bu nimæ qilsanlri amdi bi ixqa tutu qivatsam.

\section{Literary language}

tashlivitidu

He will throw away

Qaratal dialect

qilip biræj

Do it for you

tashvitidu

qip piræj kætti

ichkym kilip kætti How I want to drink ishkim kip

The above examples show that besides the abscission of syllable "li" and pronunciation "i", vowel "b" weakens to "p".
qajrimaq
Lift up
qa:rimaq

From the above examples, it can be seen that the vowel "a" pronunciation in two places changes to the long vowel "a:" and the consonant " $\mathrm{j}$ " is lost in Qaratal dialect.

Literary language

$\begin{array}{lll}\text { kirip baq } & \text { You come in here } & \text { kirip paq } \\ \text { chiqip baq } & \text { First go up here } & \text { chiqip paq } \\ \text { kylyp baq } & \text { Please smile first } & \text { kylyp paq }\end{array}$

From the above examples, it can be seen that in Qaratal dialect, when the verb ending with " $p$ " is followed by the word beginning with " $b$ ", the first consonant " $b$ " in the word beginning with "b" changes to "p".

In "nægæ bardiniz", "æ" is lost, the phenomenon that the consonant " $b$ " changes to " $v$ ", and the consonant " $r$ " is lost is occurred.

In the case of "ichkim" in the example of "ishym kilip kætti", the vowel "y" weakens to "i", the "ch" becomes to "sh", and the syllable "li" is lost. And the word "qorsiqim" (my stomach) in literature is "qussum" inQaratal dialect. Examples here show that vowel "o" weakens to "u", consonant "q" changes to "pu", and consonant "r" is lost again.

\section{ALIENATION}

This phenomenon is not common in written language, only in some local dialects in southern Xinjiang. Such as:

$\begin{array}{lll}\text { Literary language } & & \text { Variable pronunciation } \\ \text { ap`aq } & \text { White } & \text { up`paq } \\ \text { tokur } & \text { Cripple } & \text { toka } \\ \text { vapasiz } & \text { Hilly area } & \text { gopasiz } \\ \text { uvalchiliq } & & \text { ugaltiliq }\end{array}$

A hidden grievance that cannot be disclosed

\section{ASSIMILATION}

As for two different pronunciation, one of which is influenced by the second. When one or more features become identical or similar to it, the change in the flowing speech is called assimilation. According to the direction of assimilation, assimilation can be divided into progressive assimilation and reverse assimilation.

The reverse assimilation in Qaratal dialect belongs to the local dialect, mostly in the harmony of consonant pronunciation position or pronunciation method. There are both total assimilation and partial assimilation. Such as:

\section{Qaratal dialect}$$
\text { Qaratal dialect }
$$

Literary language 
A. Total Assimilation

Literary language

$\begin{array}{llc}\text { jazsa } & \text { If you write } & \text { jassa } \\ \text { onjættæ } & \text { Reading as } & \text { ojjættæ } \\ \text { qandaq } & \text { What } & \text { qandax } \\ \text { kynlyk } & \text { By date } & \text { kyllyk } \\ \text { ynlyk } & \text { High(sound) } & \text { yllyk } \\ \text { jujvætsæ } & \text { If deleted } & \text { jyjvessæ } \\ \text { aprivætsijiz } & \text { You sent } & \text { aprivessiniz }\end{array}$

The changes here are: the consonant " $\mathrm{j}$ " changes to " 3 ", the vowel "æ" changes to "e", the vowel "u" changes to "y", and the consonant "t" changes to "s" and so on. In "aprivætsiniz", the phenomenon of "æ" weakens to "e" and "t" changes to "s" is occurred.

B. Partial Assimilation

\begin{tabular}{lcc}
\multicolumn{2}{l}{ Literary language } & Qaratal dialect \\
onbir & Eleven & ombir \\
jangha & For life & jaygha
\end{tabular}

C. Reverse Assimilation

Literary language Qaratal dialect

yaghachchi Wood yaghashchi

In the most common assimilation and alienation process in Qaratal we use at present, there are also weakening and abscission phenomena. Detailed examples are as follows:

(1)The Phenomenon of Phonetic Change Such as Weakening and Abscission When Alienation

\begin{tabular}{lcl}
\multicolumn{2}{l}{ Literary language } & \multicolumn{2}{l}{ Qaratal dialect } \\
yil & Year & jil \\
yip & Line & jip \\
yighip & Incision & yighip \\
yinne & Needle & jinne \\
yigirmæ & Twenty & jigim \\
yurt & Township & jut \\
yuqi & Trace & juqi \\
yulup & Come across & julup \\
yolun & Spinal cord & julun \\
yumran & Tender & jumran
\end{tabular}

The examples above include the following: the process of "y" changes to "j", which has become a habit of local people. The " $\mathrm{j} "$ here is the lingual surface-hard palate sound, which is blocked by the airflow near the middle of the lingual surface-hard palate when you pronounce this type of sound.
" 3 " is a front lingual surface-hard palate sound, which is blocked by airflow near the front-lingual surface hard palate when you pronounce this type of sound.

\begin{tabular}{lc}
\multicolumn{2}{l}{ Literary language } \\
qorsiqim & My stomach \\
pachiqi & His feet \\
tajiqi & Be disobedient
\end{tabular}

Qaratal dialect qusghum pashighi His dormitory

jatighi

jatiqi His dormitory jatighi

In the Qaratal dialect, "q" changes to "в". The "q" here refers to the root of tongue - the uvular sound. When pronouncing this sound, it is blocked by the airflow near the root of tongue and the uvula.

\begin{tabular}{lcc}
\multicolumn{2}{l}{ Literary language } & Qaratal dialect \\
vaqti & His time & vaxti \\
hæqsiz & Free of & hæxsiz
\end{tabular}

The " $x$ " here also belongs to the root of tongue - the uvular sound, which is blocked by the airflow near the root of tongue and the uvula.

$$
\begin{array}{lr}
\text { Literary language } & \text { Qaratal dialect } \\
\text { aprivætsiniz } \quad \text { Please send it } & \text { aprivessiniz }
\end{array}
$$

In this example, " $t$ " changes to "s". The " $t$ " here is the apical - gingiva sound. When pronouncing such a sound, airflow near the gum bed through the tongue tip is blocked. "S" is the apical- tooth sound. When pronouncing this sound, airflow is blocked between the apical and the upper teeth.

$$
\begin{array}{lcc}
\multicolumn{2}{l}{\text { Literary language }} & \text { Qaratal dialect } \\
\text { qarap } & \text { Look } & \text { qalap } \\
\text { qarighili } & \text { Watching } & \text { qalighili }
\end{array}
$$

\begin{tabular}{|c|c|c|}
\hline Litera & age & Qaratal dialect \\
\hline hisab & Cast accounts & jisap \\
\hline
\end{tabular}

The word "qalap" here is one of the common words used by people in and around Qaratal County. Here "r" and "l" are both apical- gingival sounds. When pronouncing such sounds, airflow near the gum bed through the apical is blocked.

$$
\begin{array}{lcc}
\multicolumn{2}{l}{\text { Literary language }} & \text { Qaratal dialect } \\
\text { balam } & \text { My children } & \text { valam } \\
\text { jiq bermejli } & \text { Don't give too much } & \text { jiq vemejleæ } \\
\text { qurbanliq } & \text { Slaughter } & \text { quvanliq }
\end{array}
$$

The "b" in the above example is a bilabial. When speaking, the airflow is blocked on the bilabial. "V" is a labiodental. When speaking, airflow is blocked between the upper teeth and the lower lip.

The " $h$ " here is a laryngeal sound. When speaking, the airflow from the lungs rubs out between the throats. "J" is a lingual surface-hard palate sound. When pronouncing such 
sounds, airflow near the middle of the lingual surface-hard palate is blocked.

\section{TRANSPOSITION}

This phenomenon is more common in ancient Uyghur language, which is seldom used in modern Uyghur literary language. But transposition still exists in local dialect. Such as:

$\begin{array}{lrc}\text { Literary language } & \text { Qaratal dialect } \\ \text { tækshürüsh } & \text { Check } & \text { tæshkürüsh } \\ \text { uyghur } & \text { Uygur } & \text { urghuy } \\ \text { chirajini } & \text { Put your face } & \text { chirijni }\end{array}$

\section{INFLEXION AND EPENTHESIS}

\section{A. Epenthesis at the End of Sentence}

Such phonetic change phenomenon is not uncommon in Uyghur. Sometimes the whole sentence needs to be harmonious, sometimes the tone needs to be strengthened and the voice naturally increases.

$$
\begin{array}{lc}
\text { Literary language } & \text { Qaratal dialect } \\
\text { u axsham kiliptikæn } & \mathrm{u} \text { ax } \int \text { am kiptikænqum }
\end{array}
$$

I heard that he came back last night.

$$
\text { u shundaq daptikænduq u Jundaq daptikænqum }
$$

I heard that's what he said.

The - Qum and - tiqum at the end of the above sentences are all additional voices.

\section{B. Inflexion at the End of Sentence}

Such phenomenon often occurs when someone else voice or surprise. Such as:

$$
\begin{array}{ll}
\text { Literary language } & \text { Qaratal dialect } \\
\text { uningha bæk uval boluptu } & \text { unipba bæk ugal boptu }
\end{array}
$$$$
\text { He's really pathetic }
$$

$$
\text { u yaxshi ish qiliptu u yax } \int \mathrm{i} \text { i } \int \mathrm{qiptu}
$$

To torture for nothing

\section{CONCLUSION}

According to the phonetic change in modern Uyghur Qaratal pronunciation, it is analyzed that the main manifestations of phonetic change in Qaratal dialect are weakening and abscission. By comparing Qaratal dialect with modern Uyghur, we can summarize the following basic characteristics of Qaratal dialect and its similarities and differences with modern Uyghur.

- The phenomenon of phonetic change exists in both Uyghur dialect and written language. Because Qaratal dialect has different characteristics from written language, the phenomenon of phonetic change is more and more common.

- Although Qaratal dialect is not so standardized, this is caused by historical and geographical factors, so the phenomenon of phonetic change in Qaratal dialect is also in line with the law of linguistic development.

- In the phenomenon of weakening, we can see that adding the first personal pronoun after the noun of "ata/apa" is "a" to "o". Such phenomenon is not uncommon in other dialects and local dialects, but this phenomenon is particularly natural and common in Qaratal dialect, which does not affect communication. But this phenomenon does not appear with the second, the third person pronoun.

- The abscission of voice in the flowing speech of Qaratal dialects is sometimes due to the speaker is speaking fast, the omission of some consonants or vowels or syllables, which not only does not affect communication, but also makes the language succinct and lively.

- The phenomenon of epenthesis at the end of sentence is not uncommon in Uyghur. Sometimes the whole sentence is in harmony that sometimes the tone needs to be strengthened to naturally add some pronunciation. However, this phenomenon is particularly natural and common in Qaratal dialects. It is better to say that the words "qum" and "tiqum" mentioned above are all added voices.

- Qaratal dialect also has a kind of natural inertia, so through this article we can also see that Qaratal dialect requires the use of less labor-saving or more universal linguistic units in language activities in order to reduce the phenomenon of power consumption.

\section{REFERENCES}

[1] Linguistic Outline (Revised Edition) Revised by Wang Hongjun, Li Juan - Beijing: Peking University Press, 2010.1. (in Chinese)

[2] Modern Chinese Language: Revised and Enlarged Book. Volume One, Editor-in-Chief of Huang Bairong. 5th Edition. Beijing: Higher Education Press, 2011.6(in Chinese)

[3] Modern Uyghur Language, Edited by Turap Kasma Youliqi et al. Urumqi: Xinjiang University Press, 2014.5(in Chinese)

[4] Muhabati Hasimu. A Comparative Research on the main Phonetics and Grammatical Phenomena of Modern Uyghur Dialects (Uyghur)[M]. Xinjiang People's Publishing House, Urumqi, December 2012. (in Chinese)

[5] Halik, Muhabati. Linguistic Survey of Linguistics [M], Xinjiang University Press, June 1988. (in Chinese)

[6] Ma Xueliang, Litipu Wahapu, Maitireyimu Shayiti. Introduction to Linguistics (Uyghur) [M] Beijing, Nationalities Publishing House, April 1990. (in Chinese)

[7] Song Zhixiao, Li Meibei. A Brief Introduction to the Phenomenon of Phonetic Change in Uyghur Language, Language and Translation [J], March 1991. (in Chinese). 